J. clin. Path. (1952), 5, 332.

\title{
STUDIES ON THE NORMAL SERUM PANAGGLUTININ ACTIVE AGAINST TRYPSINATED HUMAN ERYTHROCYTES \\ PART I: THE MECHANISM OF AGGLUTINATION REVERSAL* \\ BY
}

\author{
THEODORE H. SPAET $\dagger$ AND BETTY W. OSTROM \\ From the Department of Medicine, Stanford University School of Medicine, San Francisco, California. \\ and the Ziskind Laboratories of the New England Center Hospital, Boston, Massachusetts
}

(RECEIVED FOR PUBLICATION JULY 15, 1952)

The technique of using trypsinated erythrocytes for the detection of "incomplete" haemagglutinating antibodies was introduced by Morton and Pickles (1947), and has supplied a valuable adjunct in the study of acquired haemolytic anaemias. It is reported to have the advantage of being simple, economical, to give rise to sharp endpoints, and produce no prozone when applied to the search for abnormal haemagglutinins (Rosenthal, Dameshek, and Burkhardt, 1951). When trypsinated cells are used in the detection of anti- $\mathrm{Rh}$ antibodies the titres obtained tend to be higher than those recorded by the use of albumin techniques and by the indirect Coombs test (Morton and Pickles, 1951; Wiener and Katz, 1951 ; Wheeler, Luhby, and Scholl, 1950); and the sera of patients with acquired haemolytic anaemia show comparable titres of agglutinins against trypsinated cells in comparison with similar tests with the albumin technique (Rosenthal et al., 1951). Trypsinated cells are especially sensitive in the detection of cold agglutinins (Bouroncle, Dodd, and Wright, 1950) and have been reported useful in the search for lysins (Dacie and de Gruchy, 1951). The major objection to their use has been their tendency to produce false positive results.

Greenwalt (1950) studied a large group of normal male subjects and found that the sera of about $1 \%$ of this group agglutinated compatible, trypsinated cells. Five minutes of incubation at $37^{\circ} \mathrm{C}$. eliminated about one-third of these " false positives." Morton and Pickles (1951) noted panagglutination against some of their trypsinated cells, which they ascribed to over-trypsinization or to an extended activity of cold agglutinins at room

\footnotetext{
*This work has been supported in part by grants from the American Cancer Society.

+Part of this work was completed during the tenure of a Damon Runyon Clinical Research Fellowship.
}

temperature. Rosenthal and Schwartz (1951a, b) performed studies which showed that panagglutination of trypsinated cells by normal compatible serum is a universal but transient phenomenon. These investigators found that in a large number of sera an agglutinin was demonstrable which was active against trypsinated cells either from a compatible donor or from the patient supplying the serum. This agglutinin was active in titres of about $1: 16$, and had the unique property of becoming ineffective following incubation at room temperature and $37^{\circ} \mathrm{C}$. Cells which were agglutinated by centrifugation immediately following exposure to serum dispersed and remained unagglutinable half an hour later if incubation in serum was continued. The speed of this agglutination reversal was proportional to the concentration of serum, proceeding most rapidly in undiluted serum. When the cells which had been previously agglutinated were allowed to become dispersed, these cells were not agglutinated by fresh serum, but the serum in which they had reversed agglutinated fresh cells. The agglutinin and reversal effect were found to be separable. The agglutinin was heat-labile and non-dialysable ; the reversal effect was heat-stable and dialysable.

The present study was undertaken to elaborate the mechanism by which a normal panagglutinin clumped trypsinated erythrocytes but lost this ability upon incubation.

\section{Methods and Materials}

Blood was obtained from members of the hospital staff, students, and clinic patients who showed no evidence of a haematological disorder.

The blood was obtained in a clean Erlenmeyer flask and defibrinated at room temperature by means of glass beads. After separation of the serum and cells the erythrocytes were trypsinated according to the technique described by Morton and Pickles (1951) 
with purified cystalline trypsin.* The cells were used within 24 hours of collection.

Agglutinations were performed in standard serological tubes. Equal amounts of the test sera and a $2 \%$ suspension of trypsinated cells were mixed at room temperature and agglutination read following a short period of slow centrifugation. Estimations of agglutination were made with the naked eye and graded as follows: $4+$, single solid clump ; $3+$, few large clumps, $2+$, numerous clumps of moderate size ; $1+$, clumping just easily visible ; \pm , questionable clumping. In reading agglutinations the tubes were tapped gently so that the button of cells was just freed from the bottom of the tube.

In all studies the trypsinated cells were tested against serum from the same blood sample or from the same subject but drawn at a different date; that is, the "auto" technique was used exclusively.

\section{Results}

General Observations. - Twenty subjects selected at random all contained the panagglutinin in their serum active against their own trypsinated erythrocytes. As in the studies of Rosenthal and Schwartz (1951a, b), the cells of all agglutinates became completely resuspended upon incubation. This phenomenon is hereafter referred to as "reversal." At room temperature the reversal time was about 30 minutes; at $37^{\circ} \mathrm{C}$. it was shortened to about 10 minutes. The observations of Rosenthal and Schwartz $(1951 \mathrm{a}, \mathrm{b})$ were confirmed in that the reversed cells were not agglutinated by the addition of fresh serum; but serum in which reversal had taken place agglutinated fresh cells.

Effect of Saline Washings on Agglutinated Cells.Cells were added to serum ${ }_{1}$ and centrifuged immediately. The serum was then removed, the agglutinated cell mass was washed three times with normal saline, and was finally suspended in a few drops of normal saline. The cells of such preparations remained strongly clumped for many hours at $37^{\circ} \mathrm{C}$., and at room temperature showed little tendency to reverse, sometimes even after standing for 24 hours. A few of these preparations did reverse at room temperature following five hours' incubation. These cells were strongly agglutinated with the addition of fresh serum. Agglutinates which had reversed at $37^{\circ} \mathrm{C}$. showed similar behaviour.

In those preparations where reversal had taken place in saline the supernatant fluid was separated. When a fresh agglutinated mass of cells was placed in this supernatant no reversal occurred. These findings suggest that spontaneous elution of the agglutinin from the cells may occur in saline, but does not occur if the concentration of agglutinin is adequately high.

Cells were mixed with serum, spun, and then incubated either at room temperature or at $37^{\circ} \mathrm{C}$. until complete agglutination reversal had taken place. They were then washed three times with normal saline and mixed with fresh serum. All such preparations showed $4+$ agglutination. When this same

\footnotetext{
*Supplied by the Armour Laboratories, Chicago, Illinois.
}

experiment was repeated, except that the washed cells were replaced into the original serum in which they had previously reversed, again they showed 4+ agglutination. It is thus evident that neither the cells nor the serum underwent any irreversible change following agglutination reversal. It was noted in addition that when a tube containing cells which had undergone agglutination reversal was placed into the refrigerator the normal cold agglutination was evident with unimpaired activity.

Effect of Repeated Exposure of Serum to Fresh Cells.-Sera were divided into three aliquots. One aliquot was treated with fresh, packed cells seven times, the cells having been centrifuged and removed immediately following mixing. The second aliquot was likewise exposed to seven changes of packed cells, but in each case the cells were allowed to undergo agglutination reversal before removal. The third aliquot served as a control, and was incubated for the same period as the others. Following treatment the three aliquots were titred for their agglutinin activity. A typical titration of such sera is shown in Table I. It can be seen that immediate removal of

TABLE I

EFFECT OF REPEATED EXPOSURE OF SERUM TO FRESH TRYPSINATED CELLS

\begin{tabular}{c|c|c|c|c|c|c}
\hline & $1: 2$ & $1: 4$ & $1: 8$ & $1: 16$ & $1: 32$ & $1: 64$ \\
\hline $\begin{array}{c}\text { Trypsinated cells against } \\
\text { normal serum }\end{array}$ & $4+$ & $4+$ & $3+$ & $1+$ & 0 & 0 \\
\hline $\begin{array}{c}\text { Trypsinated cells against } \\
\text { absorbed serum . }\end{array}$ & $2+$ & $1+$ & 0 & 0 & 0 & 0 \\
\hline $\begin{array}{c}\text { Trypsinated cells against } \\
\text { reversed serum }\end{array}$ & $4+$ & $4+$ & $3+$ & $1+$ & 0 & 0 \\
\hline
\end{tabular}

the cells causes a definite loss of agglutinin activity, whereas allowing the agglutinate to reverse in the serum does not cause a reduction in the agglutinin titre. These findings suggest that reversal is associated with elution of the agglutinin off the cell surface.

Effect of Sodium Cyanide on Agglutination.-Cells and serum were centrifuged immediately after mixing. The agglutination was read, and one drop of sodium cyanide dissolved in normal saline was added. Sodium cyanide in concentrations of $0.1 \%$ to $0.0001 \%$ was used. In dilutions of up to 1:500,000 and at a $p \mathrm{H}$ range of 5 to 9 sodium cyanide caused almost immediate reversal of strongly agglutinated cells. The cyanide effect was evident on agglutinated cells suspended either in serum or in saline. When cells which had been subjected to agglutination reversal with cyanide were washed three times with normal saline they were again agglutinated as strongly as before treatment, following the addition of fresh serum.

Sodium cyanide in concentrations of up to $1 \%$ did not affect the agglutination of A cells by anti-A serum, B cells by anti-B serum, or D+ cells by anti-D serum. Preliminary studies appear to indicate that the titre of cold and warm auto-agglutinins is reduced by the action of sodium cyanide. 
The means by which cyanide induced reversal was studied as follows. Packed cells were added to serum and removed repeatedly until the serum showed a definite loss of agglutinating ability. The agglutinated cells were washed three times with normal saline and pooled. To these pooled cells was added saline to bring the volume to that of the original absorbed serum. Three drops of $0.1 \%$ sodium cyanide were then added to this suspension, and the dispersed cells removed by centrifugation. The supernatant fluid was then dialysed in a Visking bag for 24 hours against normal saline buffered to $p H 7.4$ with onetenth its volume of Sørenson's phosphate buffer. Five $200-\mathrm{ml}$. changes of dialysing fluid were used. The resulting preparation agglutinated fresh cells, and there was no reversal at room temperature. Evidently sodium cyanide reverses the agglutination by causing elution of the agglutinin.

The effect of other known enzyme inhibitors and activators was studied. The following agents did not affect the rate of agglutination reversal in serum: saturation with carbon monoxide, $0.1 \%$ sodium azide. $25 \%$ urethane, $10 \%$ formaldehyde, $0.13 \%$ acetic acid, $0.1 \%$ ammonium hydroxide, $0.1 \%$ nitrogen mustard; $2 \mathrm{mg} . \%$ creatinine, $20 \mathrm{mg} . \%$ urea, $5 \mathrm{mg}$.\% uric acid, $0.1 \%$ solutions of d. alamine, asparagine, glycine, and tyrosine; $0.1 \%$ solutions of the cations $\mathrm{Mg}^{++}$, $\mathrm{Al}^{+++}, \mathrm{Fe}++, \quad \mathrm{Fe}^{+++}, \mathrm{Hg}^{++}, \mathrm{Ba}^{++}, \mathrm{Ca}++$, $\mathrm{Sr}^{++}, \mathrm{Cu}^{++}$; and $0.1 \%$ solutions of the anions $\mathrm{PO}_{4}^{---}, \mathrm{I}^{-}, \mathrm{Br}^{-}, \mathrm{SO}_{4}^{--}$, acetate.

Mode of Action of the Reversor Agent.-Serum was heated at $60^{\circ} \mathrm{C}$. for two hours. Such serum had no agglutinating activity, but caused reversal of washed agglutinated cells with normal activity, as has been previously reported (Rosenthal and Schwartz, 1951b.) Urine was also found to be an active reversing agent, although some urines had to be boiled to remove a slight tendency to cause non-specific agglutination. Of $2 \%$ cell suspension, $0.2 \mathrm{ml}$, and $0.2 \mathrm{ml}$. of serum were mixed, then centrifuged immediately. The agglutinated cells were then washed three times in saline and suspended in $0.2 \mathrm{ml}$. of normal serum, heat-inactivated serum, urine (neutralized to $p \mathrm{H} 7$ ) or normal saline. Periodic readings were made to determine the persistence of agglutination. It can be seen from Table II that the reversal induced by urine is actually more rapid than that by serum.

Cells from $0.2 \mathrm{ml}$. of $2 \%$ suspension were incubated with $0.2 \mathrm{ml}$. of urine or inactivated serum for one hour. The urine or serum was then removed, and $0.2 \mathrm{ml}$. of fresh serum was added. The mixture was centrifuged immediately and read for agglutination. These preparations were all negative.

In every case washing the cells three times with normal saline restored their ability to agglutinate in fresh serum.

These findings suggest that the reversor agent is adsorbed on to the cell surface in loose combination, and that its presence renders the cell refractory to the action of the agglutinin.
TABLE II

EFFECT OF URINE AND SERUM ON THE SPEED OF AGGLUTINATION REVERSAL

\begin{tabular}{|c|c|c|c|c|c|c|}
\hline & 0 & $\stackrel{5}{\min }$ & $\begin{array}{c}15 \\
\min \end{array}$ & $\begin{array}{c}30 \\
\text { min. }\end{array}$ & $\begin{array}{c}1 \\
\text { hour }\end{array}$ & $\stackrel{2}{\text { hours }}$ \\
\hline $\begin{array}{ccc}\text { Agglutinate in } & \text { normal } \\
\text { serum } & \ldots & \cdots \\
\end{array}$ & $4+$ & $4+$ & $1+$ & 0 & 0 & 0 \\
\hline Agglutinate in saline .. & $4+$ & $4+$ & $4+$ & $4+$ & $4+$ & $3-$ \\
\hline $\begin{array}{crr}\begin{array}{c}\text { Agglutinate } \\
\text { serum }\end{array} & \ldots & \\
\end{array}$ & $4+$ & $2+$ & 0 & 0 & 0 & 0 \\
\hline $\begin{array}{l}\text { Agglutinate in saline: } \\
\text { urine added . }\end{array}$ & $4+$ & 0 & 0 & 0 & 0 & 0 \\
\hline
\end{tabular}

The Effect of Increased Trypsinization.-Cells were trypsinated as before except that the concentration of trypsin was increased and the time of incubation was prolonged. Neither the rate of reversal with incubation nor the susceptibility to reversal by sodium cyanide was affected by trypsinization with enzyme solutions up to $1 \%$ incubated for up to four hours. Within the limits of the present study it does not appear that over-trypsinization universally results in "false positive" panagglutination. There is evidently a considerable degree of latitude in this test.

\section{Discussion}

On the basis of the findings reported herein it is possible to postulate the mechanism of agglutination and agglutination-reversal when trypsinated erythrocytes are exposed to compatible serum and incubated. The serum normally contains an agglutinin which is active against trypsinated cells. The rate of combination of this agglutinin with the cell surface is rapid, but its union is loose and unstable. Also present in the serum is another agent which competes with the agglutinin for the cell surface. Its combination rate is slower, but its affinity is greater than that of the agglutinin. Thus the initial agglutination follows the rapid adsorption of the agglutinin on to the erythrocyte, and the subsequent reversal appears to follow displacement of the agglutinin by the more sluggish but more tenacious reversor. That the reversor is actually adsorbed on to the cell's surface is shown by the production of inagglutinable cells when there is previous incubation of cells with reversor. However, even the reversor must be on the cell surface in rather loose combination, as it can easily be removed simply by washing the cells in normal saline. The present phenomenon does not appear to be analogous to the adsorptionelution sequence described by Hirst (1948) in relation to erythrocytes exposed to certain viruses. The cells in those studies suffered permanent loss of agglutinability by the virus following elution.

Sodium cyanide mimics the action of the naturally present reversor substance by causing 
elution of the agglutinin, although it is much more potent than the natural agent. The minute concentrations of cyanide needed to cause elution suggest that an enzyme system may be involved. It is certainly not related to residual trypsin activity, as the phenomena described are not affected by repeated washings. Moreover, trypsin activity is not affected by cyanide (Calandra et al., 1951).

The nature of the alterations on the erythrocyte surface produced by the action of trypsin is still a matter of conjecture. The ability of bacterial products to render red cells panagglutinable by normal sera has long been known (Thomsen, 1927 ; Friedenreich, 1928). Burnet, McCrea, and Stone (1946) have shown that viruses possess the same ability, and that erythrocytes modified by these agents show altered antigenic properties (Burnet and Anderson, 1947). One of the substances which was effective in inducing these changes was found to be an extract of Vibrio cholerae, and it was discovered by Pickles (1946) that erythrocytes treated with these extracts were susceptible to agglutination by "incomplete" anti-Rh antibodies. Chu and Coombs (1947) and Chu (1948) extended this finding to include a wide variety of bacteria and viruses showing that these organisms all had the ability to modify erythrocytes in such a way that there was susceptibility to panagglutination, loss of virus preceptors, and increased sensitivity to " incomplete anti-Rh." The various organisms had differing and uncorrelated potencies in effecting one or another of these modifications. Most recently Stewart and Meenan (1951) have shown that the action of trypsin differs from that of vibrio extracts and virus. Trypsin does not destroy the virus receptors in concentrations sufficient to produce a high degree of sensitivity to anti- $R \mathrm{~h}$ antibodies. In contrast trypsinized cells are much less susceptible to " $T$ " agglutination than are virus and vibrio-treated cells. Treatment of erythrocytes with periodate also renders them panagglutinable by normal sera, but this agent destroys the ability of the cells to react with anti-Rh along with the virus receptors, and produces an antigenic modification which differs from that caused by the previously mentioned agents (Stewart and Meenan, 1951 ; Stewart, 1949; Moskowitz and Treffers, 1950). It thus appears as if the modification of the erythrocyte produced by viruses and bacterial extracts is comparable to that produced by trypsin, but is by no means identical.

Ponder (1951) has studied the physical properties of erythrocytes treated with trypsin, and has been able to demonstrate minor alterations, including increased volume and mechanical fragility as well as reduced electrophoretic mobility. Other dis- cussions as to the nature of the surface alteration in these cells have been hypothetical.

Studies are now in progress which are attempting to define the nature of the normal serum agglutinin active against trypsinated erythrocytes, and the agent which causes reversal of this agglutination. It is also hoped to determine whether any relationship exists between this normal agglutinin and the agglutinins found abnormally in acquired haemolytic anaemia.

\section{Summary}

Studies were performed in which the agglutination of trypsinated human erythrocytes by normal human serum and the reversal of this agglutination upon incubation were analysed.

Cells which had agglutinated and reversed regained their agglutinability in fresh serum and in the original serum after having been washed with saline. Reversal was inhibited in saline.

It was shown that reversal was accompanied by elution of the agglutinin, and this occurred upon incubation or upon the addition of sodium cyanide.

Heated serum and urine both contain reversor agent free of agglutinin. Cells incubated with these substances are rendered inagglutinable. Agglutinability can be restored by washing.

- It is concluded that agglutinin and reversor are in competition for the red cell surface. The affinity of agglutinin is weak, but the speed of reaction is rapid. The affinity of reversor is stronger, but its speed of reaction is considerably slower.

The authors wish to thank Drs. Martin C. Rosenthal and Rose Paine for their valuable help.

\section{REFERENCES}

Bouroncle, B. A., Dodd, M. C., and Wright, C. (1950). J. Lab. clin. Med., 36, 801 .

Burnet, F. M., and Anderson, S. G. (1947). Aust. J. exp. Biol. med. Sci., 25, 213.

McCrea, J. F., and Stone, J. D. (1946). Brit. J. exp. Path., 27, 228.

Calandra, J. C., Hardt, L. L., and Stanish, E. S. (1951). Gastroenterolog $v, 19,564$

Chu, C. M. (1948). Nature, Lond., 161, 606.

- and Coombs, R. R. A.(1947). Lancet, 1, 484.

Dacie, J. V., and de Gruchy, G. C. (1951). Journal of Clinical Pathology, 4. 253.

Friedenreich, V. (1928). C. R. Soc. Biol., Paris, 98, 894.

Greenwalt. T. J. (1950). J. Lab. clin. Med., 36, 828.

Hirst, G. K. (1948). J. exp. Med., 87, 301.

Morton, J. A., and Pickles, M. M. (1947). Nature, Lond., 159, 779. (1951). Journal of Clinical P.thology, 4, 189.

Moskowitz, M., and Treffers, H. P. (1950). Srience, 111, 717.

Moskowitz, M., and Treffers, H. P. (1950). S

Ponder, E. (1951). Blood, 6, 350.

Rosenthal, M. C., Dameshek, W., and Burkhardt, R. (1951). Amer. J. clin. Path., 21, 635.

Rosenthal, M., and Schwartz, L. (1951a). Fed. Proc., 10, 332.

- (1951b). Proc. Soc. exp. Biol., N.Y., 76, 635.

Stewart, F. S. (1949). J. Path. Buct., 61, 456

and Meenan, P. N. (1951). Irish $\dot{J}$. med. S.i., 6, 6th ser., No. 311,541 .

Thomsen, O. (1927). Z. ImmunForsch., 52, 85.

Wheeler, W. E. Luhby, A. L., and Scholl, M. L. L. (1950). J. Immunol., 65, 39

Wiener, A. S., and Katz, L. (1951). Ibid., 66, 51. 